Urszula Nowicka

Wydział Nauk Ekonomicznych i Prawnych UPH

\title{
Pozbawienie władzy rodzicielskiej w polskim porządku prawnym
}

\section{Wstęp}

Pozbawienie władzy rodzicielskiej jest instytucją należącą do najsurowszej ingerencji w życie rodziny na gruncie kodeksu rodzinnego i opiekuńczego (dalej: KRO) ${ }^{1}$, jest najbardziej rygorystycznym środkiem, jaki sąd opiekuńczy może zastosować względem rodzica, który swojej władzy rodzicielskiej nie może, nie chce lub nie potrafi wykonywać w sposób właściwy. Należy jednak uświadomić sobie, że nie jest to środek o charakterze penalnym ${ }^{2}$, ponieważ jego celem nie jest karanie rodziców za nieudolność lub brak możliwości wykonywania swoich obowiązków. Sąd, orzekając o władzy rodzicielskiej, bada przede wszystkim, czy dobro dziecka jest zagrożone, a w konsekwencji celem ewentualnego orzeczenia pozbawiającego rodziców (lub jednego z nich) władzy rodzicielskiej, jest wyłącznie ochrona dziecka wraz z jednoczesnym zapewnieniem możliwości właściwego wykonywania władzy przez tego z rodziców, który może i chce ją wykonywać.

1 Por.H. HAAK , Władza rodzicielska. Komentarz, Toruń 1995, s. 143-144,T. SM YCZYŃsKi , Prawo rodzinne i opiekuńcze, Warszawa 2012, s. 240.

2 Por. M. Lech-Chełm IńskA, V. PrZybyłA, Kodeks rodzinny i opiekuńczy. Praktyczny komentarz z orzecznictwem, Warszawa 2006, s. 257 
Dobro dziecka i jego bezpieczeństwo wymaga zatem, aby w wyjątkowych, określonych prawem sytuacjach, sąd, działając z urzędu bądź na wniosek, zaingerował w nieprawidłowe relacje istniejące w rodzinie, odbierając rodzicom (lub jednemu z nich) możliwość decydowania w istotnych sprawach życia swojego dziecka. Biorąc powyższe pod uwagę prawodawca przewidział sytuacje, w których sąd zobligowany jest pozbawić rodzica władzy rodzicielskiej oraz takie, w których może, choć nie musi tego uczynić.

\section{Przesłanki obligatoryjnego pozbawienia władzy rodzicielskiej}

Zgodnie z treścią art. $111 \$ 1 \mathrm{KRO}$,jeżeli władza rodzicielska nie może być wykonywana z powodu trwałej przeszkody albo jeżeli rodzice nadużywają władzy rodzicielskiej lub w sposób rażący zaniedbują swe obowiązki względem dziecka, sąd opiekuńczy pozbawi rodziców władzy rodzicielskiej”. Kategoryczność tego sformułowania wyraża się w użyciu przez prawodawcę słowa „pozbawi”, które nie daje sądowi innej możliwości, jak tylko - w przypadku wystąpienia którejkolwiek z wymienionych w artykule sytuacji - odebranie rodzicom (lub jednemu z nich) władzy rodzicielskiej.

\subsection{Trwała przeszkoda w wykonywaniu władzy rodzicielskiej}

Prawodawca nie określił w KRO nic ponad to, że do obligatoryjnego pozbawienia władzy rodzicielskiej dochodzi po pierwsze wówczas, gdy nie ma możliwości jej wykonywania $z$ powodu trwałej przeszkody. Próby zdefiiowania owej trwałej przeszkody podjął się natomiast Sąd Najwyższy w postanowieniu z 2 czerwca 2000 r., wyjaśniając, że stanowi ona taki układ stosunków, który wyłącza sprawowanie przez rodziców władzy rodzicielskiej na stałe w tym sensie, że wedle rozsądnego przewidywania nie można ustalić czasu trwania takiego układu lub przynajmniej wiadomo, że będzie on istniał przez długi 
czas $^{3}$. Nie ma przy tym żadnego znaczenia, czy owa trwała przeszkoda wynika $\mathrm{z}$ winy rodzica ${ }^{4}$, czy też powstała i trwa niezależnie od jego woli. Aplikacja tej przesłanki oznacza bowiem jedynie udowodnienie, że przeszkoda istnieje i że ma charakter trwały ${ }^{5}$, drugorzędne znaczenie ma natomiast kwestia tego, $\mathrm{z}$ jakiego powodu ona powstała. Tym niemniej doktryna, biorąc pod uwagę analizę różnych stanów faktycznych, do przyczyn uniemożliwiających trwale wykonywanie władzy rodzicielskiej zalicza przede wszystkim zaginięcie rodzica, odbywanie przez niego długoletniej kary pozbawienia wolności, poważną chorobę związaną z przebywaniem w zamkniętym zakładzie leczniczym czy nawet poza nim, ale uniemożliwiającą wykonywanie władzy rodzicielskiej ${ }^{6}$. Analizując natomiast wypowiedzi różnych autorów można dostrzec pewną rozbieżność co do tego, czy sam fakt wyjazdu rodzica za granicę, na stałe lub na czas nieokreślony, stanowi już wystarczający argument na rzecz odebrania mu władzy rodzicielskiej nad dzieckiem pozostającym w kraju. Nie ulega wątpliwości, że taka sytuacja może wywołać zarówno stan zagrożenia dobra dziecka, jak i doprowadzić do naruszenia tego dobra ${ }^{7}$. Niezwykle trudna jest bowiem realizacja obowiązku pieczy nad osobą dziecka, nad jego majątkiem i reprezentacji (przedstawicielstwa ustawowego) w sytuacji, gdy rodzic mieszka czasem tysiące kilometrów od miejsca zamieszkania swojego dziecka ${ }^{8}$. Prawdopodobnie $\mathrm{z}$ tego względu niektórzy autorzy - jak choćby Tadeusz Smyczyński - stoją na stanowisku możliwości pozbawienia władzy rodzicielskiej z racji samego

\footnotetext{
3 Postanowienie Sądu Najwyższego z dnia 2 czerwca 2000 roku (sygn. akt II CKN 960/00), LEX nr 51976.

4 J. IgnaCzewsKi , Kodeks rodzinny i opiekuńczy. Komentarz, Warszawa 2010, s. 631 .

5 Warto bowiem dodać, iż „w razie przemijającej przeszkody w wykonywaniu władzy rodzicielskiej sąd opiekuńczy może orzec jej zawieszenie” - art. $110 \$ 1 \mathrm{KRO}$.

6 Por.Komentarz do art. 111 KRQw: K. PIETRZYKOwsKi (red.), Kodeks rodzinny i opiekuńczy. Komentarz, Wyd. 4, Warszawa 2015, s. 677.

7 Por. J. Słк , Emigracja zarobkowa rodziców i jej wpływ na wykonywanie władzy rodzicielskiej w praktyce polskich sądów rodzinnych, Warszawa 2014, s. 13

8 Por. TAM ŻE, s 10-11.
} 
stałego wyjazdu poza granice kraju9 . Większość doktryny opowiada się jednak za rozwiązaniem, zgodnie z którym nie sam fakt wyjazdu, ale dopiero połączone $\mathrm{z}$ nim zerwanie kontaktów $\mathrm{z}$ dzieckiem stanowi podstawę dla pozytywnego orzeczenia w tym względzie ${ }^{10}$. Tymczasem, opierając się na badaniach statystycznych przeprowadzonych i opublikowanych przez Jerzego Słyka należy wskazać, że pozbawienie władzy rodzicielskiej w sytuacji emigracji zarobkowej rodziców zostało orzeczone w 21, 7\% ankietowanych przypadków, wśród nich zaś ingerencja sądu we władzę rodzicielską wynikała w 47,8\% przypadków z samego tylko faktu owej emigracji zarobkowej ${ }^{1}$.

\subsection{Nadużywanie władzy rodzicielskiej}

Skoro władza rodzicielska obejmuje całokształt spraw dziecka dotyczących opieki nad jego osobą, troski o jego majątek oraz reprezentowanie, a także wychowanie dziecka, z poszanowaniem jego godności i praw, to każde nadużycie w zakresie tak określonym stanowi przesłankę dla pozbawienia władzy rodzicielskiej. Trudno byłoby stworzyć w tym względzie jakiś zamknięty katalog stanów faktycznych, a każda konkretna sprawa rozpatrywana jest indywidualnie i z uwzględnieniem specyki danego przypadku. Tym niemniej doktryna, w oparciu o wieloletnie doświadczenie i orzecznictwo, podaje przykłady najczęstszych i najbardziej charakterystycznych okoliczności, do których zalicza stosowanie przemocy fycznej i psy chicznej względem dziecka, nadmierne karanie, zmuszanie dziecka do kradzieży i innych czynów przestępczych, a także do wszelkich czynności, które narażają dziecko na utratę życia lub zdrowia, zarówno

\footnotetext{
9 Por. T. Sm yczyński, Prawo rodzinne, dz. cyt., s. 240.

10 Por. A. K. Biewński, M. PANnerT , Prawo rodzinne, Warszawa 2011, s. 208; H. НАAK , Władza rodzicielska..., dz. cyt., s. 168-169; Komentarz do art. 111 KRO w: K. Pietrzykowski (red.), Kodeks rodzinny, dz. cyt., s. 677; A. KIшŃsKA-PęKACZ , Ograniczenie, zawieszenie i pozbawienie władzy rodzicielskiej jako instytucje prawa rodzinnego służące ochronie dzieci, Studia z zakresu prawa, administracji i zarządzania UKW, t. 4/2013, s. 263.

11 Por. J. Słхк , Emigracja zarobkowa rodziców..., dz. cyt., s. 25-26.
} 
Gycznego, jak i psychicznego, zmuszanie dziecka do pracy ponad jego siły (czy to w celach zarobkowych, czy w gospodarstwie domowym), nakłanianie do żebractwa, czynów nierządnych, molestowanie seksualne, rozpijanie, wychowywanie dziecka wśród aspołecznych wartości, w pogardzie i wrogości dla drugiego rodzica ${ }^{12}$. Te wszystkie okoliczności godzą bezpośrednio w dobro dziecka i są ukierunkowane przeciwko niemu. Należy jednak wskazać, że nie tylko zachowania podjęte wprost wobec dziecka mogą stanowić argument na rzecz pozbawienia rodzica władzy rodzicielskiej. Aktualny jest przede wszystkim problem alkoholizmu jednego z rodziców oraz stosowanie przez niego przemocy względem drugiego. Wprawdzie o takiej sytuacji, w kontekście zagadnienia pozbawienia władzy rodzicielskiej, nie ma bezpośredniej wzmianki w KRO, tym niemniej znane i powszechnie cytowane jest postanowienie Sądu Najwyższego z 7 września 2000 r. (sygn. I CKN 931/00), w którym zapisano, że „nadużywanie władzy rodzicielskiej zachodzi także wówczas, gdy postępowanie rodzica obiektywnie wywiera destrukcyjny wpływ na proces wychowania i rozwoju psychicznego dziecka, choćby nie było to związane $\mathrm{z}$ subiektywnym, negatywnym nastawieniem rodzica wobec dziecka". Jest oczywiste, że tak destrukcyjny wpływ na dziecko ma agresja ojca względem matki dziecka (również odwrotnie, choć takie sytuacje na pewno należą do mniejszości), grożenie jej, zakłócanie spokoju domowego, stan nietrzeźwości. Nie ma możliwości, aby takie czyny pozostawały bez wpływu na dziecko. Nawet jeśli nie są skierowane ku niemu, to już samo demonstrowanie ich w jego obecności - jak podkreślił Sąd Najwyższy - może być ocenione jako niepoczuwanie się do troski o jego uczucia i świadome narażenie go na nieuniknione, negatywne przeżycia, stanowiące stan poważnego zagrożenia dla prawidłowego rozwoju dziecka.

\footnotetext{
${ }^{12}$ H. HAAK , Władza rodzicielska..., dz. cyt., s. 169; J. IGNACZEWsKI , Pochodzenie dziecka i władza rodzicielska po nowelizacji. Art. 61-113 KRO. KomentarzWarszawa 2009, s. 238; Komentarz do art. 111 KRQw: K. PieTRZYKowsKi (red.), Kodeks ro dzinny, dz. cyt., s. 678 .
} 
Katalog sytuacji uzasadniających wszczęcie postępowania o pozbawienie władzy rodzicielskiej jest zatem szeroki, nie można jednak nie zwrócić także uwagi na przypadki, które nie mogą zostać uwzględnione, choć niewątpliwie stanowią przedmiot kierowanych do sądu wniosków. Należy do nich sytuacja, kiedy ojciec, kierując się uczuciem do swojego dziecka, odmawia zgody na przysposobienie go przez aktualnego męża matki, choćby nawet dziecko było w nowej rodzinie wychowywane należycie i było do swojego ojczyma przywiązane ${ }^{13}$. Trudno byłoby bowiem uznać, że w ten sposób postawa ojca zagraża dobru dziecka, skoro chce on, może i potrafiako ojciec należycie sprawować władzę rodzicielską. Podobnie należy ocenić również sytuację, w której rodzic odmawia zgody na stały wyjazd dziecka za granicę, pragnąc, aby pozostało ono w kraju, co gwarantuje mu możliwość współuczestniczenia w wychowaniu dziecka ${ }^{14}$.

\subsection{Rażące zaniedbywanie obowiązków względem dziecka}

Chociaż pod względem zarówno prawnym, jak i moralnym naganne jest każde zaniedbanie dziecka, któremu rodzice winni są wychowanie i opiekę, to jednak nie każde uchybienie w tym zakresie daje podstawę dla pozbawienia władzy rodzicielskiej. Prawodawca, w odróżnieniu od poprzedniej przesłanki, której nie określił żadnym przymiotnikiem, w przypadku obecnie omawianym stanowi wyraźnie o „rażącym” zaniedbaniu, orzecznictwo zaś precyzuje, że muszą to być zaniedbania poważne lub zaniedbania o mniejszej wadze, lecz nacechowane nasileniem złej woli, uporczywością i nieporadnością ${ }^{15}$.

Jacek Ignaczewski wyróżnił dwa rodzaje spraw, w których weryfikować się będzie rażące zaniedbanie obowiązków rodziców względem

\footnotetext{
13 Postanowienie Sądu Najwyższego z dnia 8 lutego 1974 r., (sygn. akt III CRN 346/73), OSNC 1975/6/92, LEX nr 1802.

14 Postanowienie Sądu Najwyższego z dnia 1 października 1998 r. (sygn. akt I CKN 834/98), LEX nr 35068.

15 Postanowienie Sądu Najwyższego z dnia 19 czerwca 1997 r. (sygn. akt III CKN 122/97), w: J. GudowsKi , Kodeks rodzinny i opiekuńczy. Orzecznictwo, Kraków 1998, s. 379.
} 
dziecka. Pierwszą grupę stanowią sytuacje należące do patologii społecznych, nadużywanie alkoholu, narkomania i inne uzależnienia, wskutek których dochodzi do uchybień i nieprawidłowości w opiece nad dzieckiem, w zaspokajaniu jego podstawowych potrzeb higienicznych, żywieniowych czy edukacyjnych ${ }^{16}$. Takie zaniedbania nie znajdują usprawiedliwienia, wydają się jednak zwyczajną konsekwencją tkwienia rodzica w owej nieprawidłowej sytuacji, a naprawa tego stanu rzeczy możliwa jest jedynie poprzez uprzednie poradzenie sobie z własnymi problemami. Z kolei do drugiej grupy zalicza się postawy rodzica, który nie wykazuje żadnego zainteresowania swoim dzieckiem i jego losem, nie kontaktuje się z nim oraz uchyla się od obowiązku alimentowania go ${ }^{17}$. Z natury rzeczy będzie to dotyczyć sytuacji, w której rodzice dziecka nie mieszkają razem, a cały obowiązek wychowania spoczywa tylko na jednym $\mathrm{z}$ nich.

\section{Fakultatywne pozbawienie władzy rodzicielskiej}

Oprócz obligatoryjnego pozbawienia władzy rodzicielskiej, w stosunku do którego prawodawca użył kategorycznego stwierdzenia niedającego możliwości działania inaczej, przewidział także, w art. $111 \$ 1$ a KRO, że „Sąd może pozbawić rodziców władzy rodzicielskiej, jeżeli mimo udzielonej pomocy nie ustały przyczyny zastosowania art. $109 \$ 2$ pkt 5, a w szczególności gdy rodzice trwale nie interesują się dzieckiem”. Oznacza to w konsekwencji, iż prawodawca daje sędziemu możliwość odebrania władzy rodzicielskiej również wówczas, gdy wcześniej zostało wydane zarządzenie, na podstawie którego dziecko zostało umieszczone w rodzinie zastępczej lub w jakiejkolwiek innej, instytucjonalnej formie opieki nad dzieckiem (rodzinny dom dziecka, instytucjonalna piecza zastępcza, zakład opiekuńczo-leczniczy, zakład pielęgnacyjno-opiekuńczy lub zakład rehabilitacji leczniczej). Takie zarządzenie często wydaje się jako środek kontroli

\footnotetext{
${ }^{16}$ H. Ciepła, J. Ignaczewski, J. Skibińska-Adam owicz , Komentarz do spraw rodzinnych, Warszawa 2012, s. 321-324.

17 Por. TAM ŻE.
} 
nad możliwością wykonywania władzy rodzicielskiej przez rodziców, gdy jednak jego realizacja okaże się bezcelowa, sąd ma prawo ich tej władzy pozbawić. Powyższe nie oznacza jednak, że możliwość odebrania władzy rodzicielskiej jest uzależniona od uprzedniego jej ograniczenia. Owszem, jeśli było ono orzeczone, jest brane pod uwagę, nie jest jednak koniecznym krokiem w postępowaniu zmierzającym do pozbawienia władzy nad dzieckiem.

\section{Skutki pozbawienia władzy rodzicielskiej nad dzieckiem}

W świadomości społecznej instytucja pozbawienia władzy rodzicielskiej często błędnie utożsamiana jest $\mathrm{z}$ drogą prowadzącą do całkowitego zerwania relacji, tak, jak gdyby wraz z orzeczeniem sądu dziecko przestawało być dzieckiem swojego rodzica i odwrotnie - ojciec/matka przestawali być rodzicami swojego dziecka. Nic bardziej mylnego, chociaż zarówno rodzic, któremu sąd chce odebrać władzę, jak i ten, który składa do sądu stosowny wniosek, często są pełni obaw co do skutków podjętych prawnie kroków. Czego się boją? Ze strony rodzica pozbawianego władzy najczęściej chodzi o strach przed tym, że nie będzie już mógł kontaktować się z dzieckiem, z punktu widzenia drugiej strony obawa dotyczy zazwyczaj kwestii alimentów.

Takie wątpliwości, choć naturalne, nie mają jednak żadnego uzasadnienia prawnego. Nie jest prawdą, że pozbawienie władzy rodzicielskiej to utrata wszelkich praw i obowiązków wobec dziecka. Rodzic, któremu władza rodzicielska została odebrana, nie ma prawa decydować w żadnej sferze funkcjonowania dziecka, tzn. nie uczestniczy w jego wychowaniu, w decydowaniu o nim, nie występuje w jego imieniu i nie zarządza jego majątkiem. Nie ma wówczas żadnego wpływu na miejsce zamieszkania dziecka, jego ewentualny wyjazd za granicę, na wybór szkoły, leczenie itp. Nie oznacza to natomiast - co do zasady - iż nie może się z nim kontaktować. Ewentualne wątpliwości w tym zakresie rozwiązane zostały wraz z nowelizacją KRO z dnia 6 listopada 2008 r. ${ }^{18}$, w wyniku której w sposób jednoznaczny

18 Dz. U. z 2008 r., Nr 220, poz. 1431. 
zostało wskazane, że rodzice posiadają w stosunku do dzieci również określone prawa i obowiązki niestanowiące elementu władzy rodzicielskiej, a jednym z najistotniejszych w tym zakresie jest prawo do osobistej styczności z nimi ${ }^{19}$. W treści art. $113 \$ 1 \mathrm{KRO}$ zostało bowiem wyraźnie zapisane, że „niezależnie od władzy rodzicielskiej rodzice oraz ich dziecko mają prawo i obowiązek utrzymywania ze sobą kontaktów"; osobista styczność z dzieckiem nie jest bowiem atrybutem władzy rodzicielskiej ${ }^{20}$.

„Kontakty z dzieckiem - zgodnie z $\$ 2$ art. $113 \mathrm{KRO}$ - obejmuja w szczególności przebywanie z dzieckiem (odwiedziny, spotkania, zabieranie dziecka poza miejsce jego stałego pobytu) i bezpośrednie porozumiewanie się, utrzymywanie korespondencji, korzystanie z innych środków porozumiewania się na odległość, w tym ze środków komunikacji elektronicznej”. Oczywiście, jest to katalog otwarty. Forma i terminy tych kontaktów powinny być określone wspólnie przez rodziców, którzy winni kierować się w tej materii dobrem dziecka i brać pod uwagę jego rozsądne życzenia ${ }^{2}{ }^{1}$. Jeśli jednak rodzice nie są w stanie dojść do takiego porozumienia, kwestię rozstrzyga sąd opiekuńczy ${ }^{2}$.

W wyjątkowych przypadkach sąd może także, orzekając o pozbawieniu władzy rodzicielskiej, zakazać wszelkich kontaktów pomiędzy rodzicem a dzieckiem lub tylko je ograniczyć. Owo ograniczenie, zgodnie $\mathrm{z}$ art. $113^{2}$, może polegać na zakazie zabierania dziecka poza miejsce jego stałego pobytu, na daniu możliwości spotykania się z nim tylko w obecności drugiego z rodziców albo opiekuna, kuratora sądowego lub innej osoby wskazanej przez sąd, na ograniczeniu kontaktów do określonych sposobów porozumiewania się na odległość lub nawet

\footnotetext{
19 A. KIANK , Kontakty z dzieckiem, w: H. BzDAK (red.), Zbiór orzeczeń z zakresu prawa rodzinnego i opiekuńczego wraz z komentarzami. Wybrane zagadnienia, Kraków 2015, s. 378.

20 Postanowienie Sądu Najwyższego z 5 maja 2002, (sygn. akt IV CK 61 5/03, LEX nr 51982; Wyrok Sądu Najwyższego z dnia 8 września 2014 r., (sygn. akt IV CK 615/03), LEX nr 122840.

21 Art. $113^{1}$ KRO.

22 TAM ŻE.
} 
na zakazie takiego porozumiewania się. Należy jednak zwrócić uwagę, że decyzja w tym zakresie nigdy nie jest automatycznym wynikiem pozbawienia władzy rodzicielskiej, ale w każdym indywidualnym przypadku może być podjęta „jeśli wymaga tego dobro dziecka”, w szczególności, gdy ewentualny kontakt zagraża życiu, zdrowiu, bezpieczeństwu lub wpływa demoralizująco na dziecko ${ }^{2} 3$.

Rodzic pozbawiony władzy rodzicielskiej nadal zobowiązany jest do alimentacji swojego dziecka, które również zachowuje prawo do dziedziczenia po takim rodzicu. Kwestia ta nie budzi żadnych wątpliwości. Kontrowersje powoduje natomiast sytuacja odwrotna, tzn. prawo ubiegania się o alimenty oraz dziedziczenia przez rodzica pozbawionego władzy rodzicielskiej. Prawo nie reguluje takiej sytuacji w sposób bezpośredni, tzn. nie wyklucza możliwości ubiegania się o alimenty od dziecka w sytuacji, jeśli jego rodzic znalazłby się w przyszłości w niedostatku. Obowiązku alimentacyjnego nie uzależnia również od tego, czy i w jaki sposób rodzic wypełniał swoje zobowiązania rodzicielskie wobec dziecka. Tym niemniej wydaje się, że ewentualny spór w tym zakresie winien być rozstrzygany z uwzględnieniem zasad współżycia społecznego, a zatem przy aplikacji art. $144^{1} \mathrm{KRO}$, zwłaszcza jeśli pozbawienie władzy rodzicielskiej było wynikiem zawinionych zaniedbań rodzica względem dziecka. Inna będzie bowiem sytuacja rodzica przeszkodzonego nie z własnej winy w wykonywaniu władzy rodzicielskiej, a inna tego, któremu prawa te odebrano z uwagi np. na stosowaną przemoc lub zupełny brak zainteresowania dzieckiem. Wydaje się, iż podobne kryteria mogą być również uwzględnione w sytuacji dziedziczenia, które zna przecież instytucję niegodności dziedziczenia ${ }^{2}$.

\footnotetext{
23 Por. E. KaWAIA , Kodeks rodzinny i opiekuńczy. Tekst, orzecznictwo, Toruń 2003, s. 191 .

24 Por. art. 928 KC.
} 


\section{Postępowanie w sprawie o pozbawienie władzy rodzicielskiej}

Postanowienia w sprawach o pozbawienie władzy rodzicielskiej (podobnie jak w innych sprawach $\mathrm{z}$ zakresu stosunków pomiędzy rodzicami a dziećmi) mogą być wydane tylko po przeprowadzeniu rozprawy, w trybie nieprocesowym, a ich skuteczność uzależniona jest od ich uprawomocnienia się ${ }^{2}$. Postępowanie wszczyna się na wniosek lub z urzędu. Z badań przeprowadzonych przez Elżbietę Holewińską-Łapińską na podstawie danych z 21 losowo wybranych sądów rejonowych (sprawy zakończone w pierwszym półroczu 2012 r.) wynika, że w zdecydowanej większości przypadków $(62,5 \%)$ postępowanie było wszczynane z urzędu, najczęściej po informacji uzyskanej z miejskiego (lub gminnego) ośrodka pomocy społecznej. 25\% przypadków to wnioski matek kierowane przeciwko ojcom, w 6,3\% przypadków takie wnioski składali ojcowie przeciwko matkom, w pozostałych zaś przypadkach inne osoby (zwłaszcza dziadkowie) lub prokurator ${ }^{2}{ }^{6}$.

Uczestnikami postępowania o pozbawienie władzy rodzicielskiej są rodzice dziecka, a także wnioskodawca (o ile nie jest nim któryś z rodziców). Uczestnikiem nie jest natomiast samo dziecko, jak wynika z uchwały Sądu Najwyższego z 23 stycznia 1973 r. ${ }^{7}$, a także z postanowienia Sądu Najwyższego z 16 grudnia $1997 \mathrm{r}^{2}{ }^{8}$ Nie oznacza to jednak, że dziecko nie ma możliwości wypowiedzenia się w sprawie, która go dotyczy. Zgodnie bowiem z art. $576 \$ 2$ KPC „sąd w sprawach dotyczących osoby lub majątku dziecka wysłucha je, jeżeli jego

\footnotetext{
25 Por. art. 579 KPC.

26 Por. E. HoIEwIŃSKA-ŁAPIŃsKA , Orzecznictwo w sprawach o pozbawienie władzy rodzicielskiej, Prawo w działaniu. Sprawy cywilne 14/2013, s. 40-41.

27 Sygn. akt III CZP 101/71, OSNCP 1973, Nr 7-8, poz. 118 : „W sprawach o pozba wienie władzy rodzicielskiej oraz w sprawach o odebranie dziecka - dziecko nie jest uczestnikiem postępowania w rozumieniu art. 510 k.p.c.”

28 Sygn. akt III CZP 63/97, OSNCP 1998, Nr 6, poz. 108: „Uregulowany w art. 12 ust. 2 Konwencji o prawach dziecka (Dz. U. z 1991 r., Nr 120, poz. 526) obowiązek zapewnienia dziecku możliwości wypowiedzenia się w każdym postępowaniu, które jego dotyczy, nie oznacza przyznania dziecku w sprawie o pozbawienie nad nim władzy rodzicielskiej statusu uczestnika postępowania”.
} 
rozwój umysłowy, stan zdrowia i stopień dojrzałości na to pozwala, uwzględniając w miarę możliwości jego rozsądne życzenia. Wysłuchanie odbywa się poza salą posiedzeń sądowych”.

Sądem rodzinnym właściwym miejscowo w sprawach dotyczących pozbawienia władzy rodzicielskiej jest sąd rejonowy miejsca zamieszkania osoby, której postępowanie będzie dotyczyło (tzn. dziecka), gdyby zaś nie miało ono miejsca zamieszkania - wówczas sąd miejsca jego pobytu, a jeśli i tej podstawy brakuje - sąd rejonowy dla m.st. Warszawy ${ }^{2}$. We wniosku, poza oznaczeniem sądu oraz rodzaju pisma, należy podać imiona, nazwiska, adresy oraz nr PESEL wnioskodawcy oraz uczestników postępowania oraz odpowiednio umotywować swoją prośbę ${ }^{3}$, a także dołączyć wymagane załączniki (w tym akt urodzenia dziecka - skrócony, jeśli pochodzi z małżeństwa, zupełny - jeśli narodziło się w konkubinacie) oraz potwierdzenie opłaty sądowej w wysokości $40 \mathrm{zł}^{3}{ }^{31}$.

$\mathrm{W}$ toku postępowania sąd przesłuchuje rodziców małoletniego dziecka, a także ewentualnych świadków, jeśli zostali wskazani we wniosku. Bardzo często kieruje też rodzinę na badania do Rodzinnego Ośrodka Diagnostyczno-Konsultacyjnego, gdzie biegli sądowi psychologowie, pedagodzy, a czasem również lekarze i psychiatrzy wyrażają swoją opinię na temat relacji rodzinnych, wydolności rodziców, ewentualnie występujących zaburzeń i patologii ${ }^{32}$. Nowelizacją KRO i KPC z 25 czerwca 2015 r. $^{3}$ dokonano ponadto zmiany art. 509 KPC, w wyniku której w obecnym stanie prawnym sprawy o pozbawienie władzy rodzicielskiej rozpoznaje sąd w składzie jednego sędziego ${ }^{3}$.

\footnotetext{
29 Por. art. 569 KPC.

30 E. MarszałKowsKa-Krześ , Postępowanie nieprocesowe w sprawach osobowych oraz rodzinnych, Wrocław 2012, s. 53-54.

31 Art. 23 ust. 1 Ustawyz dnia 28 lipca 2005 r. o kosztach sądowych w sprawach cywilnych, Dz. U. z 2005 r., Nr 167, poz. 1398.

${ }^{32}$ K. MiłeK-Giertuga ，Formy ingerencji sqdu w wykonywanie władzy rodzicielskiej, Studia Lubuskie 1 (2005), s. 175.

${ }^{3}$ Dz. U. z 2015 r., poz. 1062.

${ }^{3}$ Dotychczas obowiązywała zasada, że w sprawach o przysposobienie, o pozbawienie lub ograniczenie władzy rodzicielskiej, w I instancji sąd rozpoznaje w składzie
} 
Istotną konsekwencją takiego zapisu jest możliwość - dotąd nieistniejąca - łącznego rozpoznawania spraw dotyczących władzy rodzicielskiej oraz kontaktów pomiędzy rodzicami i dziećmi ${ }^{35}$.

\section{Przywrócenie władzy rodzicielskiej}

Zgodnie $\mathrm{z}$ art. $111 \$ 2 \mathrm{KRO}$ „w razie ustania przyczyny, która była podstawą pozbawienia władzy rodzicielskiej, sąd opiekuńczy może władzę rodzicielską przywrócić”. Z zapisu tego wynika kilka istotnych informacji. Po pierwsze taka, że pozbawienie władzy rodzicielskiej nie jest decyzją nieodwracalną, ale uzależnioną od trwania lub ustania jej przyczyny. Przywrócenie nie dokonuje się jednak automatycznie, li tylko na tej podstawie, że przyczyna pozbawienia ustała. Przede wszystkim ocena takiego stanu rzeczy należy każdorazowo do sądu, który musi wziąć pod uwagę szereg okoliczności. W doktrynie podkreśla się nawet, że samo ustanie przesłanki, która stanowiła przyczynę pozbawienia władzy rodzicielskiej, nie jest obligatoryjne dla sądu ${ }^{36}$. Istotę stanowi bowiem dopiero gwarancja, że jeśli sąd podejmie pozytywną decyzję, to w jej wyniku nie nastąpi naruszenie dobra dziecka ${ }^{3}$. W tym celu przeprowadza się postępowanie, często powtórnie korzysta z opinii RODK, ocenia, czy i jakie pozytywne zmiany zaszły w postawach rodzica oraz jego relacjach z dzieckiem. A i to nie daje jeszcze pewnej decyzji pozytywnej, prawo stanowi bowiem, że sąd „może”, a nie że „musi” władzę rodzicielską przywrócić. Wszystko zależy od dobra dziecka, przy którego ocenie należy

jednego sędziego i dwóch ławników. Obecnie jedynie sprawy o przysposobienie w I instancji sąd rozpoznaje we wskazanym wyżej składzie, natomiast sprawy o pozbawienie lub ograniczenie władzy rodzicielskiej tak, jak sprawy o ustalenie kontaktów, rozpoznaje sąd w składzie jednego sędziego. - Por. A. KianK , Kontakty $z$ dzieckiem..., dz. cyt., s. 376.

35 Por. TAM ŻE.

36 Por. J. StRZEBińczyK , Prawo rodzinne, Warszawa 2013, s. 286.

37 Por. A. KinŃsKa-PęKACZ , Ograniczenie, zawieszenie i pozbawienie..., dz. cyt., s. 259. 
uwzględnić również jego więzy emocjonalne z osobami, pod których opieką aktualnie pozostaje.

\section{Zakończenie}

Punktem odniesienia wszelkich powyższych rozważań jest dobro małoletniego dziecka. Ono stanowi nadrzędną wartość, ze względu na którą prawodawca przewidział na gruncie prawa rodzinnego i opiekuńczego również instytucję pozbawienia władzy rodzicielskiej. Ma ona wszak na celu ochronę dziecka, jego życia, zdrowia, bezpieczeństwa, prawidłowego rozwoju. Tę wartość winien mieć przed oczyma sędzia decydujący w sprawach tak daleko ingerujących w relacje rodzinne. Ale powinien kierować się nią również rodzic, który decyduje się na złożenie do sądu wniosku o pozbawienie władzy rodzicielskiej. Niestety, nie są odosobnione przypadki, kiedy tego typu prośby kierowane są do sądów z motywów całkowicie obcych istocie omawianej instytucji, gdy rodzic występuje do sądu $\mathrm{z}$ chęci zemsty lub dokuczenia drugiemu. Należy przeto apelować i przypominać każdemu, że najważniejszą kwestią w relacjach rodzinnych jest dobro dziecka i to ono ma przyświecać wszystkim osobom zaangażowanym w jakikolwiek sposób w sądową regulację relacji pomiędzy rodzicami a dziećmi.

\section{Deprivation of parental authority in Polish legal order}

\section{Summary}

ThFamily and Guardianship Code regulates the legal institutions of deprivation of parental authority. Alsubject of the article is therefore an analysis of this institution in the Polish legal order. It is a very important institution and is the most severe interference in a family's life under Polish law, it is the most rigorous measure a court can apply to a parent who can not or does not want to exercise his parental authority appropriately. When resorting to such measures the courts should fist of all act upon the principle of wellbeing of the child that amounts to one of the most precious values enshrined in the legal system. 